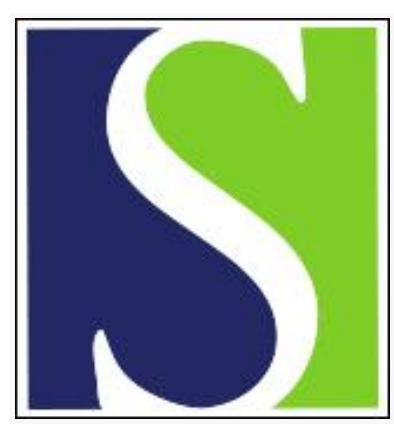

Scand J Work Environ Health 1992;18(2):90-96

https://doi.org/10.5271/sjweh.1596

Issue date: 01 Apr 1992

Mortality study of ethanol and isopropanol production workers at two facilities.

by Teta MJ, Perlman GD, Ott MG

Affiliation: Health, Safety and Environmental Affairs, Union Carbide Chemicals and Plastics Co Inc, Danbury, Connecticut 06817.

This article in PubMed: www.ncbi.nlm.nih.gov/pubmed/1604278

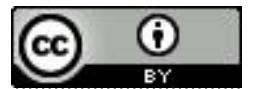




\title{
Mortality study of ethanol and isopropanol production workers at two facilities
}

\author{
by $\mathrm{M}$ Jane Teta, DrPH, ${ }^{1}$ Gary D Perlman, $\mathrm{MPH}^{2}{ }^{2} \mathrm{M}$ Gerald Ott, $\mathrm{PhD}^{3}$
}

\begin{abstract}
TETA MJ, PERLMAN GD, OTT MG. Mortality study of ethanol and isopropanol production workers at two facilities. Scand J Work Environ Health 1992;18:90-6. The mortality experience of alcohol process workers $(\mathrm{N}=1031)$ from two chemical plants was followed from the early 1940 s to 1983 . Reported associations of the production of ethanol and isopropanol by the strong-acid process with upper respiratory tract cancers, heart disease, and lympho- and reticulosarcoma were tested with both external and internal comparisons. Excesses of cancers of the larynx, buccal cavity, and pharynx, based on very small numbers, were observed. There was one death due to sinus cancer. It could not be concluded that there were work-related effects on mortality due to heart disease or lympho- or reticulosarcoma. Workers assigned to the production of isopropanol by the weak-acid method showed no evidence of excess cancer mortality ( 0 observed, 1.9 expected cancer deaths). The absence of major risks among strong-acid workers can be explained by the initiation of engineering controls and health monitoring that took place after the original medical observations.
\end{abstract}

Key terms: buccal cavity, diethyl sulfate, diisopropyl sulfate, larynx, pharynx, sinus, strong acid, sulfuric acid, upper respiratory tract, weak acid.

The Union Carbide Chemicals and Plastics Company Inc, has produced ethanol and isopropanol at several of its locations. The earliest production method was the strong-acid process in which the respective alkene, ethylene or propylene, was combined with concentrated sulfuric acid. Alkyl sulfates (diethyl and diisopropyl) were the main by-products, which were then combined with water and hydrolyzed to the respective alcohols. In about 1950 isopropanol production changed from the strong- to the weak-acid process, which is currently in use today. The strong and weak processes for the production of isopropanol and ethanol have been described in detail by others (1). Since about 1968 ethanol has been produced with a new process not involving acids.

In 1952 Weil et al (2) reported an excess of tumors of the upper respiratory tract among isopropanol strong-acid workers at the company's plant in South Charleston, West Virginia. He also described followup toxicology investigations of various possible occupational exposures, particularly isopropyl oil, a byproduct of the process, which produced inconclusive results. Wright, in 1979, proposed a new potential carcinogen - diisopropyl sulfate (3). The International

\footnotetext{
1 Health, Safety and Environmental Affairs, Union Carbide Chemicals and Plastics Co Inc, Danbury, Connecticut, United Statcs.

${ }^{2}$ Yale University School of Medicine, Department of Epidemiology and Public Health, Health and Aging Project, New Haven, Connecticut, United States.

3 BASF Corporation, Parsippany, New Jersey, United States.
}

Reprint requests to: Dr MJ Teta, Health, Safety and Environmental Affairs $P_{2}$, Union Carbide Chemicals and Plastics Co Inc, 39 Old Ridgebury Road, Danbury, CT 06817, USA.
Agency for Research on Cancer has classified diethyl sulfate as a probable human carcinogen on the basis of sufficient evidence from animals and limited evidence from humans (4). Lynch et al (1) suspected the alkyl sulfates as risk factors for laryngeal cancer, as the observed incidence rates were higher than expected in a study of the Exxon Corporation's alcohol process workers. The authors concluded that the effects were attributable to the strong-acid ethanol process rather than to the weak-acid process, since this method, which used weaker concentrations of sulfuric acid, produced lower levels of alkyl sulfates. In 1984, a case-referent incidence study of laryngeal cancer in the same Exxon facility found increased risk associated with potential exposure to sulfuric acid (5). A small cohort of isopropanol production workers employed by the Shell Oil Company in the United Kingdom included one death due to sinus cancer ( 0.02 expected) and none due to cancers of the larynx or buccal cavity and pharynx (0.06 expected) for the period 1950-1975 (6). The authors did not state whether the process was either strong or weak acid. More recently, a study of 618 Shell isopropanol strong-acid workers at a Texas plant failed to find any deaths (1948-1983) due to laryngeal or sinus cancers (reference 7 and Marsh GM, Enterline PE, McCraw D. The Dear Park mortality study: final report to the Shell Oil Company, December 1987). There were two deaths from cancers of the buccal cavity and pharynx ( 0.98 expected).

The Union Carbide Corporation conducted a casereferent study at its South Charleston plant. The study indicated an excess of deaths from non-Hodgkin's lymphoma for men assigned to strong-acid ethanol or isopropanol production (8). The evidence for a possible work-related effect was weakened, however, by the 
absence of a duration-response trend. In a preliminary cohort analysis of the workers assigned to these same units for $\geq 10$ years, an increased risk of heart disease was suggested. In an exploratory study of solvent exposure and heart disease among rubber workers, Wilcosky \& Tyroler (9) reported an association between inhaled ethanol and ischemic heart disease.

Two follow-up investigations have since been conducted of Union Carbide's workers to examine possible associations of assignment to alcohol process units with upper respiratory cancers, non-Hodgkin's lymphoma, and heart disease, namely, a more complete examination of the South Charleston strong-acid workers with a longer period of observation and a cohort study of employees assigned to either the strong- or weak-acid process at another company location in Texas City, Texas.

\section{Subjects and methods}

Workers assigned to the process units of interest at the two facilities $(\mathrm{N}=1031)$ were readily identified from information developed in collaboration with the $\mathrm{Na}$ tional Institute for Occupational Safety and Health, as part of previously conducted plant-wide cohort mortality studies $(10,11)$. Work histories for both the South Charleston and Texas City plants were collected from the time of the plant start-ups in 1928 and 1941, respectively, through 1978, the closing date of the studies.

The observation period, but not the work history data, has been extended for both cohorts through 1983 with the use of company records and the National Death Index (12). Vital status was ascertained through 1983 for $99 \%$ of the subjects from each location (tables 1 and 2). The South Charleston workers represented an older population (42 versus $15 \%$ deceased), hired earlier ( 87 versus $56 \%$ hired prior to 1949 ) and with longer employment ( 83 versus $54 \%$ with $\geq 10$ years' assignment to the plant).

\section{South Charleston plant}

The South Charleston plant produced ethanol from 1930 through 1968 and isopropanol from 1928 through 1949 with the strong-acid method (table 3). Veteran employees reported that exposures were very high initially because it was a leaky process which was carried out in a closed building. The windows were later removed to provide natural ventilation. There was also misting of the sulfuric acid and other agents during the opening of the reaction vessels. After the identification of upper respiratory tumors by Weil et al (2), the isopropanol process was modified to reduce worker exposures significantly. Medical monitoring of workers was also initiated. Subsequently, a redesigned plant was built that removed contact with the reactants by situating operators in a well-ventilated remote-control office.

All male employees with departmental account numbers indicating assignment to either or both of the two strong-acid units at the South Charleston plant were selected from the computerized work history file, which included employees who had ever worked at this location between 1940 and 1978 . The study group con-

Table 1. Vital status, as of 31 December 1983, of the workers in the production of ethanol and isopropanol by the strongacid method in South Charleston, according to date of hire and length of employment.

\begin{tabular}{lrrrc}
\hline & Total & Alive & Deceased Unknown \\
\cline { 2 - 5 } Hire date & & & & \\
1921-1940 & 280 & 118 & 161 & 1 \\
$1941-1944$ & 106 & 73 & 33 & - \\
1945-1949 & 83 & 61 & 21 & 1 \\
1950 or later & 69 & 58 & 9 & 2 \\
Length of & & & & \\
employment & & & & \\
$<1$ year & 21 & 12 & 9 & - \\
1-9 years & 73 & 48 & 23 & 2 \\
$>10$ years & 444 & 250 & 192 & 2 \\
\hline Total & 538 & 310 & 224 & 4 \\
\hline
\end{tabular}

Table 2. Vital status, as of 31 December 1983, of the workers in the production of ethanol and isopropanol by the strongand weak-acid methods in Texas City, according to race, date of hire, and length of employment.

\begin{tabular}{|c|c|c|c|c|}
\hline & Total & Alive & Deceased & Unknown \\
\hline \multicolumn{5}{|l|}{ Race } \\
\hline $\begin{array}{l}\text { White } \\
\text { Nonwhite } \\
\text { Unknown }\end{array}$ & $\begin{array}{r}455 \\
23 \\
15\end{array}$ & $\begin{array}{r}381 \\
18 \\
13\end{array}$ & $\begin{array}{r}69 \\
5 \\
2\end{array}$ & $\frac{5}{-}$ \\
\hline \multicolumn{5}{|l|}{ Hire date } \\
\hline $\begin{array}{l}1941-1944 \\
1945-1949 \\
1950 \text { or later }\end{array}$ & $\begin{array}{l}119 \\
156 \\
218\end{array}$ & $\begin{array}{r}86 \\
127 \\
199\end{array}$ & $\begin{array}{l}32 \\
27 \\
17\end{array}$ & $\begin{array}{l}1 \\
2 \\
2\end{array}$ \\
\hline \multicolumn{5}{|l|}{$\begin{array}{l}\text { Length of } \\
\text { employment }\end{array}$} \\
\hline $\begin{array}{l}<1 \text { year } \\
1-9 \text { years } \\
\geq 10 \text { years }\end{array}$ & $\begin{array}{r}95 \\
132 \\
266\end{array}$ & $\begin{array}{r}79 \\
104 \\
229\end{array}$ & $\begin{array}{l}15 \\
25 \\
36\end{array}$ & $\begin{array}{l}1 \\
3 \\
1\end{array}$ \\
\hline Total & 493 & 412 & 76 & 5 \\
\hline
\end{tabular}

Table 3. Periods of production of ethanol and isopropanol by process and location.

\begin{tabular}{lcc}
\hline Process & $\begin{array}{c}\text { South } \\
\text { Charleston }\end{array}$ & Texas City \\
\hline Ethanol & & \\
$\quad$ Strong-acid process & $1930-1968$ & $1941-1968$ \\
$\quad$ Hydration of ethylene & & $1969-1985$ \\
Isopropanol & & \\
$\quad$ Strong-acid process & $1928-1949$ & $1941-1950$ \\
Weak-acid process & & 1949 -present \\
\hline
\end{tabular}


sisted of $538 \mathrm{men}, 370$ of whom had worked in ethanol strong-acid production only and 135 of whom had worked in isopropanol strong-acid production only and 33 of whom had assignments to both.

\section{Texas City plant}

The Texas City plant produced ethanol by the strongacid process from its start-up in 1941 through 1968. Similar to the South Charleston plant, tanks were hosed clean with water by laborers. In addition there was some misting of sulfuric acid during the opening of the reaction vessels. The production of crude ethanol was, however, never in a closed building.

The technology used for ethanol production after 1968 did not use acids, instead a process was applied involving catalyzed vapor-phase hydration of ethylene. The Texas City plant ceased ethanol production altogether in the mid-1980s. Isopropanol was produced by the strong-acid process from 1941 through 1950. Starting in 1949 the weak-acid isopropyl process was initiated and, for a two-year period (1949-1950), both methods were operating, using some of the same workers. Isopropanol continues to be produced at Texas City by the weak-acid process.

In the early years of the Texas City operation there was some interchange of workers with South Charleston for start-up or training. The strong-acid units in the two plants had the same department codes. In these cases, the assumption was made that the assignment was to South Charleston if the year of assignment was prior to 1941 and to Texas City if after 1941.

The computerized work history file for the plant population included month and year of each department assignment. The study group therefore consisted of male workers assigned one month or more from 1941 through 1978 to ethanol production by the strongacid process or isopropanol production with the strongor weak-acid process and workers in closely related areas. The latter included sulfuric acid production and concentration units and acetone and ester units, since these were in close proximity to the units of interest and frequently interchanged workers. The total cohort included $493 \mathrm{men}$. Of these, 405 had only one assignment (242 ethanol, 114 isopropanol weak-acid, 49 isopropanol strong-acid). A total of $316 \mathrm{men}$ had assignments to ethanol strong-acid units and 92 had assignments to isopropanol strong-acid units.

\section{Methods of analysis}

A modified life-table approach was used to calculate the values for the standardized mortality ratio (SMR) (13). Death rates were obtained from the University of Pittsburgh for the United States and for the region in which the plants were located. Cancer death rates were available for 1950-1982. Noncancer death rates included the years 1962-1982 and required back extrapolation to 1950 on the assumption of the same rates as those for 1962-1969. Person-years were calculated from the date of first assignment to the units of interest or 1 January 1950, whichever was more recent, to death, loss to follow-up, or 31 December 1983, whichever occurred first. The total and cause-specific SMR values were defined by age at risk, calendar year, interval from onset of assignment, duration of assignment, type of assignment (strong-acid, weak-acid, both) and year of assignment. Values for the $95 \%$ confidence interval $(95 \% \mathrm{CI})$ were calculated on the assumption that observed deaths were distributed as a Poisson variable $(14,15)$.

Separate analyses were conducted for nonwhite men from Texas City, who were compared with the general nonwhite male population of the United States. The 15 men with race unknown were considered white for these purposes. Since race data has not been systematically collected at South Charleston, the total study group from this location was compared with the general white male population of the United States.

Internal analyses were also conducted for duration of assignment comparisons adjusting for age, calendar year, and time since first assignment. Men not assigned to the units of interest were used as the reference group $(16,17)$.

\section{Results}

\section{South Charleston plant}

Table 4 presents findings for the South Charleston workers. The SMR for all causes of death was 1.00 (95\% CI 0.9-1.1) and the SMR for total cancer was $1.10(95 \%$ CI $0.8-1.4)$. For persons assigned $\geq 10$ years to these units, the cancer SMR decreased to 102 . There was one death due to laryngeal cancer $(0.7 \mathrm{ex}-$ pected), two due to cancers of the buccal cavity or pharynx (1.5 expected), and no deaths due to sinus cancer. There was a statistically significant excess of lymphosarcoma and reticulosarcoma, on the basis of five observed and 0.9 expected deaths (SMR $5.60,95 \% \mathrm{CI}$ 1.8-13.0). No deaths occurred from these causes among the men assigned more than five years to these units.

The SMR for heart disease was 1.08 , but, for the men assigned $\geq 10$ years to these units, the mortality rate was $44 \%$ greater than for the general population ( $95 \%$ CI 1.0-2.0). We examined this finding by hire date to study the possibility of selection of less healthy men into the work force during the years of highest military induction into World War II (1943-1945). There was a statistically significant threefold excess of heart disease mortality $(95 \% \mathrm{CI} 1.1-6.5)$ in the group which had the longest assignments and which had been hired during these war years. For those not hired between 1943 and 1945, there were 26 deaths due to heart disease (20.2 expected) among those assigned $\geq 10$ years to these units $(95 \% \mathrm{CI} 0.8-1.9)$.

When regional rates for Kanawha and Putman counties were used for the comparison (the South Charles- 
ton plant being located in Kanawha County and Putman County being an adjoining county), the overall SMR for heart disease was 0.89 . For those assigned 10 years or more, it was 1.20. With the exclusion of those hired between 1943 and 1945, the heart disease mortality rate for those with long-term assignments was similar to expectation (SMR 1.07, 95\% CI 0.71.6).

The results were similar when internal comparisons were used (table 5). There was no significant durationresponse trend among those not hired during the years of highest induction, although the relative risk was greatest for the group with the longest assignments (SMR 1.33, 95\% CI 0.9-2.0).

To test for acute effects, we also examined the heart disease mortality patterns for unusual excesses during the period of active employment through five years after last employment. The relative risk (RR) estimates for both external and internal comparisons were no higher than those obtained for the entire observation period.

\section{Texas City plant}

Strong-acid workers. The workers assigned to ethanol and isopropanol production at Texas City were examined to test the consistency of findings reported for South Charleston and other facilities. Table 6 presents the results for the workers assigned in this study group to the strong-acid process. The SMR for all causes was 0.74 , and that for all cancer was 1.02 . Similar to the South Charleston cohort, the number of deaths was greater than expected for cancer of the larynx (1 observed versus 0.3 expected) and cancer of the buccal cavity or pharynx ( 1 observed versus 0.7 expected), on the basis of very small numbers. There were no deaths identified due to sinus cancer, lymphosarcoma or reticulosarcoma ( 0.4 expected). Three deaths were observed due to tuberculosis ( 0.3 expected). All three persons were hired between 1941 and 1945. Two of the three men worked about one month at the plant.

The overall SMR for heart disease was 0.63 , a significant deficit. The SMR for those assigned $\geq 10$ years was $1.16(95 \%$ CI $0.4-2.5)$ on the basis of six observed

Table 4. Observed and expected ${ }^{a}$ deaths through 1983 for the men assigned (1928-1969) to strong-acid units at the South Charleston plant. (SMR = standardized mortality ratio, $95 \% \mathrm{Cl}=95 \%$ confidence interval)

\begin{tabular}{|c|c|c|c|c|c|c|}
\hline \multirow[b]{2}{*}{ Cause of death } & \multicolumn{2}{|c|}{ Observed $(\mathrm{N})$} & \multirow[b]{2}{*}{$\begin{array}{l}\text { Expected } \\
(\mathrm{N})\end{array}$} & \multicolumn{2}{|c|}{$\mathrm{SMR}^{\mathrm{b}}$} & \multirow[b]{2}{*}{$\begin{array}{l}95 \% \mathrm{Cl} \text { for } \\
\text { all the } \\
\text { workers }\end{array}$} \\
\hline & $\begin{array}{l}\text { Among all } \\
\text { the workers }\end{array}$ & $\begin{array}{l}\text { Among } \\
\text { workers with } \\
\text { assignment } \\
\text { durations of } \\
\geq 10 \text { years }\end{array}$ & & $\begin{array}{l}\text { Among all } \\
\text { the workers }\end{array}$ & $\begin{array}{l}\text { Among } \\
\text { workers with } \\
\text { assignment } \\
\text { durations of } \\
\geq 10 \text { years }\end{array}$ & \\
\hline Malignant neoplasms & 53 & 11 & 48.1 & 1.10 & 1.02 & $0.8-1.4$ \\
\hline Buccal cavity and pharynx & 2 & - & 1.5 & . & $\cdots$ & $0.2-4.8$ \\
\hline Respiratory system & 15 & 3 & 17.1 & 0.88 & 0.79 & $0.5-1.4$ \\
\hline $\begin{array}{l}\text { Bronchus, trachea and lung } \\
\text { Larynx }\end{array}$ & $\begin{array}{r}14 \\
1\end{array}$ & $\begin{array}{l}2 \\
1\end{array}$ & $\begin{array}{r}16.1 \\
0.7\end{array}$ & $\begin{array}{l}0.87 \\
\cdots\end{array}$ & 0.56 & $\begin{array}{r}0.5-1.5 \\
0-8.0\end{array}$ \\
\hline Central nervous system & 4 & 1 & 1.4 & . & . & $0.8-7.3$ \\
\hline Lymphatic and hematopoietic tissue & 9 & 2 & 4.4 & 2.05 & $\cdots$ & $0.9-3.9$ \\
\hline $\begin{array}{l}\text { Lymphosarcoma and reticulosarcoma } \\
\text { Leukemia and aleukemia }\end{array}$ & $\begin{array}{l}5 \\
2\end{array}$ & $-\frac{}{1}$ & $\begin{array}{l}0.9 \\
1.8\end{array}$ & $\begin{array}{l}5.60^{\star \star} \\
1.12\end{array}$ & $\begin{array}{l}\cdots \\
\cdots\end{array}$ & $\begin{array}{l}1.8-13.0 \\
0.1-4.0\end{array}$ \\
\hline All heart disease & 105 & 32 & 97.5 & 1.08 & 1.44 & $0.9-1.3$ \\
\hline Other & 66 & 11 & 79.5 & 0.83 & 0.64 & $0.6-1.1$ \\
\hline All causes & 224 & 54 & 225.1 & 1.00 & 1.07 & $0.9-1.1$ \\
\hline
\end{tabular}

a Expected deaths based on white mortality rates through 1982 in the United States.

b SMR not caiculated when the numbers of observed and expected deaths were both less than five.

$* \mathrm{P}<0.01$.

Table 5. Internal ${ }^{a}$ comparison of heart disease mortality (1950-1983) for white men hired before 1943 or after 1945 and as signed to strong-acid production units at the South Charleston and Texas City plants by duration of assignment (RR = relative risk, $95 \% \mathrm{Cl}=95 \%$ confidence interval)

\begin{tabular}{|c|c|c|c|c|c|c|c|c|c|c|c|c|}
\hline \multirow[b]{3}{*}{ Plant } & \multirow{2}{*}{\multicolumn{2}{|c|}{$\begin{array}{c}\text { Never assigned } \\
\text { to strong-acid } \\
\text { unit }\end{array}$}} & \multicolumn{9}{|c|}{ Duration of assignment to strong-acid unit } & \multirow{3}{*}{$\begin{array}{l}\text { Test } \\
\text { for } \\
\text { trend }\end{array}$} \\
\hline & & & \multicolumn{3}{|c|}{$<1$ years } & \multicolumn{3}{|c|}{$1-9$ years } & \multicolumn{3}{|c|}{$\geq 10$ years } & \\
\hline & RR & $\begin{array}{l}\text { Ob- } \\
\text { served } \\
\text { deaths } \\
\text { (N) }\end{array}$ & RR & $\begin{array}{l}\text { Ob- } \\
\text { served } \\
\text { deaths } \\
\text { (N) }\end{array}$ & $95 \% \mathrm{Cl}$ & RR & $\begin{array}{l}\text { Ob- } \\
\text { served } \\
\text { deaths } \\
\text { (N) }\end{array}$ & $95 \% \mathrm{Cl}$ & RR & $\begin{array}{l}\text { Ob- } \\
\text { served } \\
\text { deaths } \\
\text { (N) }\end{array}$ & $95 \% \mathrm{Cl}$ & \\
\hline $\begin{array}{l}\text { South } \\
\text { Charleston }\end{array}$ & 1.00 & 1864 & 0.92 & 21 & $0.6-1.4$ & 0.99 & 37 & $0.7-1.4$ & 1.33 & 25 & $0.9-2.0$ & $P=0.48$ \\
\hline Texas City & 1.00 & 290 & 0.44 & 3 & $0.1-1.4$ & 0.61 & 10 & $0.3-1.1$ & 1.39 & 5 & $0.6-3.4$ & $P=0.32$ \\
\hline
\end{tabular}

a Adjusted for age, calendar year, and time since hire; only includes strata with person-years for all three levels of duration. 
Table 6. Observed and expected deaths through 1983 for white men assigned (1941-1969) to strong-acid units at the Texas City plant. (SMR = standardized mortality ratio, $95 \% \mathrm{Cl}=95 \%$ confidence interval)

\begin{tabular}{|c|c|c|c|c|c|c|}
\hline \multirow[b]{2}{*}{ Cause of death } & \multicolumn{2}{|c|}{ Observed $(\mathrm{N})$} & \multirow[b]{2}{*}{$\begin{array}{l}\text { Expected } \\
\text { (N) }\end{array}$} & \multicolumn{2}{|c|}{ SMR $^{b}$} & \multirow[b]{2}{*}{$95 \% \mathrm{Cl}$} \\
\hline & $\begin{array}{l}\text { Among all } \\
\text { workers }\end{array}$ & $\begin{array}{l}\text { Among } \\
\text { workers with } \\
\text { assignment } \\
\text { durations of } \\
\geq 10 \text { years }\end{array}$ & & $\begin{array}{l}\text { Among all } \\
\text { workers }\end{array}$ & $\begin{array}{l}\text { Among } \\
\text { workers with } \\
\text { assignment } \\
\text { durations of } \\
\geq 10 \text { years }\end{array}$ & \\
\hline Tuberculosis & 3 & - & 0.3 & . & $\cdots$ & $2.1-29.2$ \\
\hline Malignant neoplasms & 20 & 3 & 19.7 & 1.02 & 1.03 & $0.6-1.6$ \\
\hline Buccal cavity and pharynx & 1 & - & 0.7 & $\cdots$ & $\cdots$ & $0.0-8.4$ \\
\hline Respiratory system & 9 & 1 & 7.6 & 1.18 & $\cdots$ & $0.6-2.2$ \\
\hline $\begin{array}{l}\text { Bronchus, trachea and lung } \\
\text { Laryngeal cancer }\end{array}$ & $\begin{array}{l}8 \\
1\end{array}$ & 1 & $\begin{array}{l}7.2 \\
0.3\end{array}$ & $\begin{array}{l}1.10 \\
\cdots\end{array}$ & $\cdots$ & $\begin{array}{l}0.5-2.2 \\
0.1-18.6\end{array}$ \\
\hline Central nervous system & 2 & 1 & 0.7 & $\cdots$ & $\cdots$ & $0.3-9.8$ \\
\hline Lymphatic and hematopoietic tissue & 3 & - & 2.0 & $\because$ & $\cdots$ & $0.3-4.5$ \\
\hline $\begin{array}{l}\text { Lymphosarcoma and reticulosarcoma } \\
\text { Leukemia and aleukemia }\end{array}$ & $\overline{2}$ & $\overline{-}$ & $\begin{array}{l}0.4 \\
0.7\end{array}$ & $\begin{array}{l}\cdots \\
\cdots\end{array}$ & $\cdots$ & $\begin{array}{l}0.0-9.0 \\
0.3-10.3\end{array}$ \\
\hline All heart disease & 22 & 6 & 34.7 & $0.63^{\star}$ & 1.16 & $0.4-1.0$ \\
\hline Other & 19 & 1 & 32.2 & $0.59^{*}$ & 0.24 & $0.4-0.9$ \\
\hline All causes & 64 & 10 & 86.9 & $0.74^{*}$ & 0.81 & $0.6-0.9$ \\
\hline
\end{tabular}

a Expected deaths based on male rates in the United States in 1950-1984.

SMR not calculated when the numbers of observed and expected deaths were both less than five.

$\star \mathrm{P}<0.05$.

Table 7. Selected characteristics of decedents from cancer of the upper respiratory tract who were assigned to strong-acid alcohol production at two Union Carbide plants. (ETH = ethanol strong-acid unit, ISO = isopropanol strong-acid unit)

\begin{tabular}{|c|c|c|c|c|c|c|}
\hline \multirow{2}{*}{$\begin{array}{l}\text { Cause of death } \\
\text { Laryngeal cancer }\end{array}$} & \multirow{2}{*}{$\begin{array}{c}\text { Location } \\
\text { Texas City }\end{array}$} & \multicolumn{2}{|c|}{$\begin{array}{l}\text { Duration of } \\
\text { assignment } \\
\text { (year) }^{\mathrm{a}}\end{array}$} & \multirow{2}{*}{$\begin{array}{c}\begin{array}{c}\text { Exposure } \\
\text { period }\end{array} \\
1950 \mathrm{~s}\end{array}$} & \multirow{2}{*}{$\begin{array}{c}\begin{array}{c}\text { Age at } \\
\text { death } \\
\text { (years) }\end{array} \\
56\end{array}$} & \multirow{2}{*}{$\begin{array}{c}\begin{array}{c}\text { Latency } \\
\text { (years) }\end{array} \\
28\end{array}$} \\
\hline & & 10 & $(\mathrm{ETH})$ & & & \\
\hline Laryngeal cancer & South Charleston & 18 & (ISO) & $1920 s-1940 s$ & 76 & 57 \\
\hline $\begin{array}{l}\text { Buccal and } \\
\text { pharyngeal cancer }\end{array}$ & Texas City & 8 & (ISO) & $1940 \mathrm{~s}$ & 44 & 10 \\
\hline $\begin{array}{l}\text { Buccal and } \\
\text { pharyngeal cancer }\end{array}$ & South Charleston & 5 & (ISO) & $1940 \mathrm{~s}$ & 54 & 19 \\
\hline $\begin{array}{l}\text { Buccal and } \\
\text { pharyngeal cancer }\end{array}$ & South Charleston & 3 & $(\mathrm{ETH})$ & $1950 \mathrm{~s}$ & 53 & 32 \\
\hline Sinus cancerb & South Charleston & 6 & (ISO) & $1930 \mathrm{~s}$ & 41 & 8 \\
\hline
\end{tabular}

a Rounded to the nearest integer.

b Death prior to 1950; not included in the statistical analysis.

and 5.2 expected deaths. The results of the internal comparisons were similar to those seen in the external comparisons and did not suggest a duration-response trend. There was a nonsignificant elevated relative risk (RR 1.39, 95\% CI 0.6-3.4) for those not hired between 1943 and 1945 and assigned $\geq 10$ years (table 5).

There were five deaths ( 8.0 expected) and two cancer deaths ( 1.5 expected) among the men for whom race information was available, and it was indicated that these men were nonwhite. The two cancers were of the large intestine and prostate.

Weak-acid workers. Since the only existing process today for producing isopropanol is weak acid, those assigned to this process and not to strong-acid units were examined separately. The mortality experience for the white weak-acid workers included seven deaths $(9.2$ expected), five of which were attributed to external causes (1.7 expected). There were no cancer deaths (1.9 expected, $95 \% \mathrm{CI} 0-1.9$ ), and no deaths of nonwhite weak-acid workers.

\section{Discussion}

Occupational physicians in the early 1940 s at the South Charleston plant first raised the concern that a carcinogen might be present in the isopropanol strongacid process (2). Prior to 1950 seven neoplasms of the respiratory tract were identified in active workers assigned to this unit for 6-16 years during the 1930s and 1940s. These involved the lung $(\mathrm{N}=1)$, paranasal sinuses $(\mathrm{N}=4)$, and vocal cords $(\mathrm{N}=2)$. Additional cases of upper respiratory tract neoplasms were found in a search of insurance claims for employees who died while actively employed. 
The present investigation, which followed all strongacid workers (in both ethanol and isopropanol production) from 1950 to 1983 in both the South Charleston and the Texas City plants, showed weak associations with cancers of the upper respiratory tract. When the results for laryngeal cancer were combined for the two plants, there was a total of two observed and 1.0 expected deaths in the two plants (1 observed versus 0.2 expected for those assigned $\geq 10$ years of exposure) (table 7). Medical records located for the Texas City laryngeal cancer decedent indicated that he was diagnosed in 1960 and 1961 with hepatitis, bleeding peptic ulcers, pancreatitis, depression, and alcoholism. After five years in the Navy in World War II, he had been hospitalized for depression. He worked as an operator in the ethanol strong-acid unit from 1951 to 1960 , from which he was transferred to the sulfuric acid unit in January 1961, as recommended by the plant physician.

There were four incident laryngeal cancer cases over a similar observation period reported for the Exxon alcohol process workers, the excess being fivefold (1). The Shell studies were based on death certificates, similar to the present study, and failed to identify any deaths due to laryngeal cancer $(6,7)$. The mortality studies may have underestimated the risk of developing laryngeal cancer since this disease has been reported to have a survival rate of over $50 \%$ (18).

For buccal cavity and pharyngeal cancers (lip; tongue; salivary gland; gum; mouth; oro-, naso-, and hypopharynx) three deaths were observed and 2.2 were expected in the Union Carbide plants (SMR 1.36). The assignment duration for these persons ranged from three to eight years. Inclusion of the Shell data for this category yields a summary risk estimate of 1.52 ( $5 \mathrm{ob}-$ served versus 3.3 expected, 95\% CI 0.5-3.5). The Exxon data included five cancers of the lip, gum, or mouth, an approximate twofold excess, based on proportional cancer mortality ratios. These data are consistent with the early medical observations, but do not suggest as strong a finding.

There are several possible explanations for the absence of much greater excesses of upper respiratory tract cancers among the strong-acid workers studied since 1950. As a result of early observations, the process was significantly modified at the Union Carbide facility to reduce worker exposure. In addition medical surveillance was initiated at regular intervals. Workers with evidence of nasal and sinus abnormalities were transferred to other units. Employees with long-term assignments were also gradually transferred out. Finally, the incidence of these neoplasms would be underestimated by the use of death certificates for case identification, since they are not necessarily fatal diseases. The present study did include, however, a larger population of potentially exposed men, since terminated and retired workers were also traced.

Three agents have been suspected of causing respiratory tract tumors in isopropanol strong-acid workers, the by-product isopropyl oil, the isopropyl sulfate intermediates, and sulfuric acid. The latter two are biologically plausible since they are capable of causing chronic irritation of the nose and throat at high exposure levels. Weil et al (2) suspected isopropyl oil, a somewhat volatile hydrocarbon. The present study does not contribute evidence to Weil's "quest" for a carcinogen. It does provide reassurance that the etiologic agent's effects on former strong-acid workers have been controlled by appropriate measures. $\mathrm{Al}$ though based on small numbers, it also suggests that similar effects will not be seen in workers assigned to isopropanol production by the weak-acid method, a manufacturing technology in use at Texas City for over 40 years. The Texas City weak-acid workers who were never assigned to the strong-acid process have not experienced any deaths due to cancer. About two cancer deaths would have been expected.

The findings related to lymphosarcoma and reticulosarcoma and heart disease among the South Charleston strong-acid workers were not confirmed by data from the Texas City or Shell workers assigned to the same processes. There were no deaths among the Texas City workers because of lymphosarcoma or reticulosarcoma. Among those assigned $\geq 10$ years to the strongacid units, there were six deaths from heart disease and 5.2 expected.

The heart disease findings for the South Charleston men with long-term assignment were partially explained by selection of less healthy men for employment during World War II. This phenomenon has been observed by several investigators (19-21). After exclusion of those hired during the years of highest induction into the military, there remained a weak nonsignificant excess for those assigned $\geq 10$ years to strong-acid units. Regional differences accounted for most of the remaining excess. This result was not unexpected since cardiac mortality in West Virginia was $16 \%$ above the national level in 1980 , excess mortality occurring in most counties in the state (22).

Four of the five South Charleston decedents with lymphosarcoma or reticulosarcoma were assigned to ethanol and one to isopropanol strong-acid units. Three of the five cases had been assigned for two months or less, and for two others the length of assignment was between one and nine years. Internal comparisons showed a significant excess only in the group that had worked less than one year (RR 8.6, 95\% CI 2.6-28.8) and a significant negative trend with duration of assignment $(P=0.04)$. Selection of workers with long-term assignments out of the units by plant physicians could have dampened or reversed a duration-response trend. It is unlikely that this phenomenon would occur after such short assignments for cases with these diseases and not for cases of the other diseases of a priori interest. The South Charleston decedents with cancer of the upper respiratory tract had assignment durations which ranged from 3 to 18 years (table 7). Failure to identify deaths due to lymphosar- 
coma or reticulosarcoma in the Texas City and Shell populations also argues against a relationship with assignment to strong-acid production.

This mortality study followed 1031 alcohol process workers from two chemical plants over a 40-year period. The availability of comparison mortality rates constrained the person-year analysis to begin in 1950. An additional 10 deaths occurred in the 1940s, all in the South Charleston study group. One of these was attributable to sinus cancer. Worker assignments to the strong-acid units extended as far back as 1921 for the South Charleston plant, which was one of the original manufacturing facilities to produce isopropanol in the United States. Only five men who worked $\geq 10$ years in the South Charleston strong-acid isopropanol units were still alive as of 1983. Four of these men have since died of causes unrelated to tumors of the upper respiratory tract.

The South Charleston study group was a censored population. Subjects qualified provided they were active in 1940 or hired thereafter. No information was available (other than the observation of Weil et al) about those who terminated their work prior to 1940 . The Texas City study group was an "inception" cohort and virtually complete, since the study subjects were identified from the plant start-up in 1941. As a result, they were a younger population with a shorter period since first exposure and likely lower average exposures to the agents associated with the strong-acid process. The data from both populations support the original conclusions that an upper respiratory tract carcinogen is present in the strong-acid process but do not confirm the preliminary findings from the South Charleston group in relation to heart disease and lymphopoietic cancers. Finally, although the study was based on small numbers, no evidence of carcinogenicity was seen that was related to the weak-acid process, which is the currently used method for isopropanol production.

\section{Acknowledgments}

The authors wish to thank Mr T Soto for his technical support and Ms C Gulick for her manuscript preparation.

\section{References}

1. Lynch J, Hanis NM, Bird MG, Murray KJ, Walsh JP. An association of upper respiratory cancer with exposure to diethyl sulfate. J Occup Med 1979;21:333-41.

2. Weil CS, Smyth HF, Nale TW. Quest for a suspected industrial carcinogen. Arch Ind Hyg Occup Med 1952; $5: 535-47$.

3. Wright $U$. The hidden carcinogen in the manufacture of isopropyl alcohol. In: Deichman WB, ed. Toxicology and occupational medicine. New York, NY: Elsewier, North Holland, Inc, 1979:93-8.
4. International Agency for Research on Cancer (IARC). Overall evaluations of carcinogenicity: an updating of IARC monographs volumes 1 to 42. Lyon: IARC, 1987. (IARC monographs on the evaluation of the carcinogenic risk of chemicals to humans; suppl 7.)

5. Soskolne CL, Zeighami EA, Hanis NM, Kupper LL, Herrmann N, Amsel J, et al. Laryngeal cancer and occupational exposure to sulfuric acid. Am J Epidemiol 1984;120:358-69.

6. Alderson MR, Rattan NS. Mortality of workers on an isopropyl alcohol plant and two MEK dewaxing plants. $\mathrm{Br} \mathrm{J}$ Ind Med 1980;37:85-9.

7. Marsh GM, Enterline PE, McCraw D. Mortality patterns among petroleum refinery and chemical plant workers. Am J Ind Med 1991;19:29—42.

8. Ott MG, Teta MJ, Greenberg HL. Lymphatic and hematopoietic tissue cancer in a chemical manufacturing environment. Am J Ind Med 1989;16:631-43.

9. Wilcosky TC, Tyroler HA. Mortality from heart disease among workers exposed to solvents. J Occup Med 1983;25:879-85.

10. Rinsky RA, Ott MG, Ward E, Greenberg H, Halperin W, Leet T. Study of mortality among chemical workers in the Kanawha Valley of West Virginia. Am J Ind Med 1988;13:429-38.

11. Austin SG, Schnatter AR. A cohort mortality study of petrochemical workers. J Occup Med 1983;25:304-12.

12. Teta MJ, Ott MG, Schnatter AR. An update of mortality due to brain neoplasms and other causes among employees of a petrochemical facility. J Occup Med 1991;33:45-51.

13. Ott MG, Carlo GL, Steinberg S, Bond GG. Mortality among employees engaged in chemical manufacturing and related activities. Am J Epidemiol 1985;122:31122.

14. Marsh GM, Preininger M. OCMAP: a user-oriented cohort mortality analysis program. Am Stat 1980;34: 245-6.

15. Bailar JC, Ederer F. Significance factors for the ratio of a Poisson variable to its expectation. Biometrics 1964; 20:639.

16. Mantel N. Chi-square tests with one degree of freedom; extensions of the Mantel-Haenszel procedure. J Am Stat Assoc 1963;58:690-700.

17. Hakulinen T. A Mantel-Haenszel statistic for testing the association between a polychotomous exposure and a rare outcome. Am J Epidemiol 1981;113:192-7.

18. Steenland K, Schnorr T, Beaumont J, Halperin W, Bloom $\mathrm{T}$. Incidence of laryngeal cancer and exposure to acid mists. $\mathrm{Br} \mathrm{J}$ Ind Med 1988;45:766-76.

19. Wen CP, Tsai SP, Weiss NS, Gibson RL. Long-term mortality study of oil refinery workers: V. comparison of workers hired before, during, and after World War II (1940 - 1945) with a discussion of the impact of study designs on cohort results. Am J Ind Med 1986;9:17180.

20. Dupree EA, Cragle DL, McLain RW, Crawford-Brown DJ, Teta MJ. Mortality among workers at a uranium processing facility, the Linde Air Products Company Ceramics Plant, 1943-1949. Scand J Work Environ Health $1987 ; 13: 100-7$.

21. Bond GG, Lipps TE, Cook RR. Mortality comparisons of chemical workers hired before, during and after World War II (1941-1945). Am J Ind Med 1989;15: 335-42.

22. Baron RC, Haddy LE, Dickson CW. Excess mortality from heart disease in West Virginia. WVa Med J 1988; $84: 557-62$.

Received for publication: 25 March 1991 